\title{
Penerapan Strategi Manajemen Pengetahuan untuk Meningkatkan Kinerja Institusi Pendidikan dalam Menghadapi Revolusi Industri 4.0
}

Submitted Date:

8 Januari 2021

Accepted Date:

30 April 2021
Mohammad Kurniadi Rasyid

Universitas Pendidikan Indonesia kurniadirasyid@upi.edu

\author{
Agus Rahayu
}

Universitas Pendidikan Indonesia agus rhy08@upi.edu

Lili Adi Wibowo

Universitas Pendidikan Indonesia

liliadiwibowo@upi.edu

\section{Suggested Citation:}

Yuniarsih \& Amartiwi. (2019). Implementasi Manajemen Pengetahuan pada Perguruan Tinggi Swasta di Kabupaten Garut. Jurnal Wacana Kinerja: Kajian Praktis-Akademis Kinerja dan Administrasi Pelayanan Publik. 22. 10.31845/jwk.v22i2.166.

Abstract:

The purpose of this study was to find out the effect of implementing knowledge management strategies on the performance of educational institutions in the face of the industrial revolution 4.0. The approach used in this research is a quantitative approach. The sample used in this study is the academic community in one of the private universities in Serpong. The data analysis technique used in the study was Partial Least Square Structural Equation Modeling (PLS-SEM). The results showed that the application of knowledge management strategies was proven to significantly affect the performance of educational institutions. Knowledge management strategies have also been shown to have a strong influence in improving human relations among students. Relationships among humans can be a mediating variable for the relationship between knowledge management strategies and educational institution performance and have the same influence as the direct influence of knowledge management strategies on the performance of educational institutions.

Keywords: knowledge management strategies, performance of educational institutions, industrial revolution 4.0.

Abstrak:

Tujuan penelitian ini adalah untuk mengetahui pengaruh penerapan strategi manajemen pengetahuan terhadap kinerja institusi pendidikan dalam menghadapi revolusi industri 4.0. Pendekatan yang digunakan dalam penelitian ini adalah pendekatan kuantitatif. Sampel yang digunakan dalam penelitian ini adalah civitas akademika di salah satu perguruan tinggi swasta di Serpong. Teknik analisis data yang digunakan dalam penelitian ini adalah Partial Least Square Structural Equation Modeling (PLS-SEM). Hasil penelitian menunjukkan bahwa penerapan strategi manajemen pengetahuan terbukti berpengaruh signifikan terhadap kinerja institusi pendidikan. Strategi manajemen pengetahuan juga telah terbukti memiliki pengaruh yang kuat dalam meningkatkan hubungan antar manusia di antara siswa. Hubungan antar manusia dapat menjadi variabel mediasi untuk hubungan antara strategi manajemen pengetahuan dan kinerja lembaga pendidikan dan memiliki pengaruh yang sama dengan pengaruh langsung strategi manajemen pengetahuan terhadap kinerja lembaga pendidikan

Kata Kunci: knowledge management strategies, performance of educational institutions, industrial revolution 4.0.

JEL Classification: 015 


\section{Latar Belakang}

Di era industry 4.0 terjadi perubahan yang sangat cepat disegala bidang yang diakibatkan dari perkembangan teknologi informasi yang sangat cepat (Schawab, 2016). Hal ini jika tidak dipersiapkan dengan benar maka dapat mengancam kehidupan organisasi/perusahaan. Karnawati (2017) menjelaskan efek dari revolusi industri 4.0 ini akan menghilangkan 35 persen jenis pekerjaan dalam kurun waktu lima tahun kedepan. Pekerjaan yang selama ini dilakukan oleh manusia pelan-pelan akan digantikan oleh perangkat teknologi digital. Kondisi ini mengakibatkan perlu adanya perubahan diberbagai bidang agar tetap survive dan ini juga berlaku juga di bidang pendidikan karena potret masa depan bangsa sangat dipengaruhi kualitas penyelenggaraan pendidikannya. Namun sayangnya berdasarkan hasil kajian yang dibuat The Organisation for Economic Co-operation and Development (OECD) pada tahun 2018 posisi Indonesia untuk kemampuan pelajar-pelajarnya dalam hal membaca, matematika dan wawasan keilmuan berada dibawah 75 negara lain

Lase (2019) menjelaskan perlu adanya perbaikan dalam sistem pendidikan sehingga sumber daya manusia yang dihasilkan oleh berbagai lembaga pendidikan siap memenuhi tuntutan yang diminta oleh revolusi industri 4.0. Apabila mutu lulusan perguruan tinggi memenuhi tuntutan ini maka ini menunjukkan bahwa perguruan tinggi mempunyai kualitas yang baik, sebagaimana yang disampaikan Hidayat (2013) bahwa mutu sebuah perguruan tinggi juga diukur dari mutu akademik yang dimiliki lulusan. Sesuai Undang-undang Nomor 12 Tahun 2012 tentang Pendidikan Tinggi pasal 4 dijelaskan pendidikan tinggi berkewajiban menjadikan bangsa Indonesia menjadi bangsa yang cerdas, para sivitas academiknya inovatif, responsif, kreatif, terampil, berdaya saing, dan kooperatif dan mengembangkan ilmu pengetahuan dan teknologi. Sementara berdasarkan Undangundang Nomor 14 Tahun 2005 dosen bertugas mentransformasikan, mengembangkan, dan menyebarluaskan IPTEK (Undang-undang Nomor 14 Tahun 2005 tentang Guru dan Dosen, 2005).

Manajemen pengetahuan sebagai salah satu konsep yang cukup popular didalam mengelola proses pengetahuan yang ada didalam suatu organisasi diharapkan dapat membantu proses penyiapan SDM yang mempunyai kemampuan dan diterima di revolusi industry 4.0. Strategi manajemen pengetahuan adalah sebuah strategi pengelolaan pengetahuan yang digunakan oleh organisasi dan juga perusahaan untuk mengidentifikasi, menciptakan, menjelaskan, dan mendistribusikan pengetahuan yang ada di dalam organisasi tersebut (Stewart, 1990). Iqbal, A., Latif, F., Marimon, F., Sahibzada, U.F. and Hussain, S. (2019) menyatakan bahwa manajemen pengetahuan terbukti berpengaruh secara positif bagi kinerja organisasi. Menurut President of knowledge management Society Indonesia, Jann Hidajat Tjakraatmadja (2019) jika Revolusi industri 4.0 tidak direspon secara arif dan bijaksana oleh suatu organisasi maka akan berbalik menjadi suatu ancaman serius. Ditambah lagi pengetahuan yang dimiliki dosen secara individual, ternyata belum bisa terdistribusikan dengan baik hal ini disebabkan banyak perguruan tinggi khususnya perguruan tinggi swasta belum mempunyai sistem informasi yang memadai, sebagai media untuk menyalurkan atau mendistribuskan pengetahuan secara cepat, tepat, dan akurat (Yuniarsih \& Amartiwi, 2019). Sementara itu keberhasilan sebuah organisasi atau perusahaan juga dipengaruhi bagaimana organisasi tersebut memperhatikan sisi hubungan sesama manusia diantara para anggotanya atau karyawannya (Siagian 2012). Sehingga apabila hubungan sesama manusia didalam sebuah organisasi baik maka kinerja sumber daya manusia didalamnya juga baik.

Berdasarkan fenomena yang dijelaskan di atas maka tujuan penelitian yang dirumuskan oleh peneliti adalah untuk menganalisis penerapan strategi manajemen pengetahuan dalam rangka meningkatkan kinerja institusi pendidikan dalam menjawab tuntutan revolusi industry 4.0. Selanjutnya, penelitian ini juga bertujuan untuk menganalisis pengaruh manajemen pengetahuan terhadap hubungan sesama manusia di institusi pendidikan serta menganalisis pengaruh hubungan sesama manusia terhadap kinerja institusi pendidikan.

\section{Literature Review}

\section{Strategi Manajemen Pengetahuan}

Strategi manajemen pengetahuan merupakan strategi penerapan manajemen pengetahuan (knowledge management) untuk menghadapi kondisi lingkungan yang cepat berubah. Penelitian dari Walsh, J.N.\& Lannon J. (2020) menemukan bahwa organisasi yang menerapkan manajemen pengetahuan siap melakukan perubahan strategis, pindah ke pemrograman terintegrasi, dan menggunakan proses reformulasi manajemen pengetahuan untuk mencapai tujuan strategis mereka. Teece, Pisano dan Schuen (1997) menjelaskan bahwa lingkungan persaingan global pada dasarnya dinamis dan kompleks. Oleh karenanya perusahaan juga harus mempunyai kemampuan yang dinamis. Kemampuan dinamis dipandang sebagai perpanjangan dari pandangan berbasis sumber daya (RBV), yang menunjukkan bahwa setiap organisasi memiliki profil yang berbeda dari sumber daya berwujud dan tidak berwujud dan kapabilitas, dan perbedaan ini menjelaskan variasi dalam posisi kompetitif 


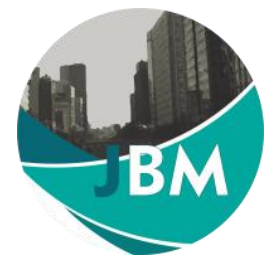

organisasi dan kinerja mereka (Barney, 1991). Sedangkan manajemen pengetahuan dapat didefinisikan sebagai kegiatan melakukan penyimpanan (storage), penyebarluasan (dissemination), penilaian (assessment), penerapan (application), perbaikan (refinement), dan penciptaan pengetahuan baru yang dibutuhkan organisasi (Frost 2010).

Sejarah manajemen pengetahuan dimulai pada tahun 1990, beberapa konsultan manajemen memulai program Strategi manajemen pengetahuan in-house, dan di beberapa perusahaan AS, Eropa, dan Jepang. Knowledge management diperkenalkan di media populer pada tahun 1991, ketika Tom Stewart menerbitkan "Brainpower" di majalah Fortune. Manajemen pengetahuan saat ini dipandang sebagai sesuatu yang dibutuhkan. Hal ini karena sumber ekonomi tidak lagi berdasar pada modal, sumber daya alam, atau tenaga kerja, tapi pada pengetahuan (Peter Drucker, 1994). Iqbal, A., at al., (2019) menyatakan bahwa manajemen pengetahuan terbukti berpengaruh secara positif bagi kinerja organisasi. Gold,et al (2001) dalam teorinya menyatakan untuk menilai pelaksanaan manajemen pengetahuan pada sebuah organisasi ada empat dimensi yang perlu dilihat yaitu: knowledge acquitision, knowledge conversion, knowledge application dan knowledge protection. Kemudian Lowson (2003) mengembangkannya menjadi enam dimensi untuk menilai penerapan knowledge management pada sebuah organisasi, yakni knowledge creation process, knowledge capture process, knowledge organization process, knowledge storage process, knowledge dissemination process dan knowledge application process. Dengan penjelasan tersebut maka strategi manajemen pengetahuan mempunyai makna strategi perusahaan melakukan proses knowledge management untuk kondisi lingkungan yang berubah dengan cepat. Penggunaan istilah ini digunakan oleh Jutidharabongse, et al. (2020) saat membuktikan pengaruhnya untuk meningkatkan competitive adventage enterpreneuership di Thailand.

\section{Kinerja Institusi Pendidikan}

Lase (2019) menjelaskan pengembangan kurikulum saat ini dan masa depan harus melengkapi kemampuan siswa dalam dimensi akademik, keterampilan hidup, kemampuan untuk hidup bersama dan berpikir secara kritis dan kreatif termasuk juga keterampilan interpersonal, berpikir global, dan literasi media dan informasi. Al-Rahmi, W. Mugahed, et. Al. (2018) membuktikan adanya beberapa faktor yang mempengaruhi kinerja institusi pendidikan di institusi pendidikan diantaranya adalah penggunaan media sosial.

Berdasarkan laporan Pusat Penelitian dan Pengembangan Prestasi Akademik (CRIRES) (2005), kinerja institusi pendidikan adalah sebuah konstruk untuk mengukur prestasi, pengetahuan, dan keterampilan siswa. Untuk mengukur prestasi akademik, pendidik menggunakan berbagai jenis penilaian yang berkelanjutan yang membawa beberapa informasi berharga tentang proses pembelajaran (Linn dan Gronlund, 1995). Proses penilaian prestasi harus dapat memotivasi dan memberikan tujuan (Hargis, 2003).

Menurut Hecklau, Galeitzke, Flachs \& Khol (2016) terdapat 4 kompetensi yang harus dikuasai dalam menghadapi di revolusi industri 4.0 yaitu: kompetensi teknik, kompetensi metodologi, kompetensi sosial dan kompetensi personal. Sementara menurut hasil survei World Economic Forum (2018). menunjukan bahwa terdapat sepuluh skill yang dibutuhkan memasuki era revolusi industri 4.0. Adapun top ten skill demand (WEForum, 2018) adalah sebagai berikut: analytical thinking and innovation; complex problem solving; chritical thinking and analysis; active learning and learning strategies; creativity, originality and initiative; attention to detail; emotional intelligence; reasoning, problem solving and ideation; leadership and social influence dan Coordination and time management. Menurut Robbins (2006) indikator untuk mengukur kinerja secara individu ada 5 indikator, yaitu kualitas kerja, kuantitas. ketepatan waktu, efektivitas, kemandirian.

\section{Hubungan Sesama Manusia}

Menurut Davis (2009) Hubungan sesama manusia adalah interaksi antara seseorang dengan orang lain didalam sebuah organisasi atau perusahaan. Reece, Brant, dan Howie (2008), ada tujuh dimesi hubungan sesama manusia, yakni: komunikasi (communications), kesadaran diri (self-awareness), penerimaan diri (selfacceptance), motivasi (motivation), kepercayaan (trust), keterbukaan diri (self-disclosure) dan penyelesaian konflik (conflict resolution). Elton Mayo dalam Liliweri (2014) menyatakan produktivitas kerja tidak ditentukan oleh faktor cahaya dan besaran upah, melainkan oleh bagaimana organisasi memberikan kesempatan bagi pegawai untuk melakukan hubungan sesama manusia. 
Hipotesis yang diajukan dalam penelitian ini adalah:

H1: Semakin efektif strategi manajemen pengetahuan maka semakin tinggi kinerja institusi pendidikan.

H2: Semakin efektif strategi manajemen pengetahuan maka semakin maka semakin kuat hubungan sesama manusia.

H3: Semakin kuat hubungan sesama manusia maka semakin tinggi kinerja institusi pendidikan.

\section{Metode Penelitian}

Pendekatan yang digunakan dari penelitian ini merupakan pendekatan kuantitatif, dan tipe penelitian yang digunakan dalam penelitian ini adalah explanatory research. Teknik analisis data yang digunakan dalam penelitian menggunakan Partial Least Square Structural Equation Modelling (PLS -SEM). Ghozali (2006) menjelaskan bahwa PLS adalah metode analisis yang bersifat soft modeling karena tidak mengasumsikan data harus dengan pengukuran skala tertentu, yang berarti jumlah sampel dapat kecil (dibawah 100 sampel). Chin (2015) menyatakan minimal ukuran sampel yang digunakan PLS-SEM ialah 30-100 ukuran sampel. Sampel yang digunakan dalam penelitian ini adalah 45 orang civitas akademika dari perguruan tinggi ITI, Puspitek Serpong. Tahap pengujian PLS Path Modeling dilakukan dengan menguji outer model dan Inner model. Dimensi variabel manajemen pengetahuan, Hubungan sesama manusia dan kinerja institusi pendidikan dapat dilihat pada pada Gambar 1.

\section{Gambar 1. Model Penelitian}

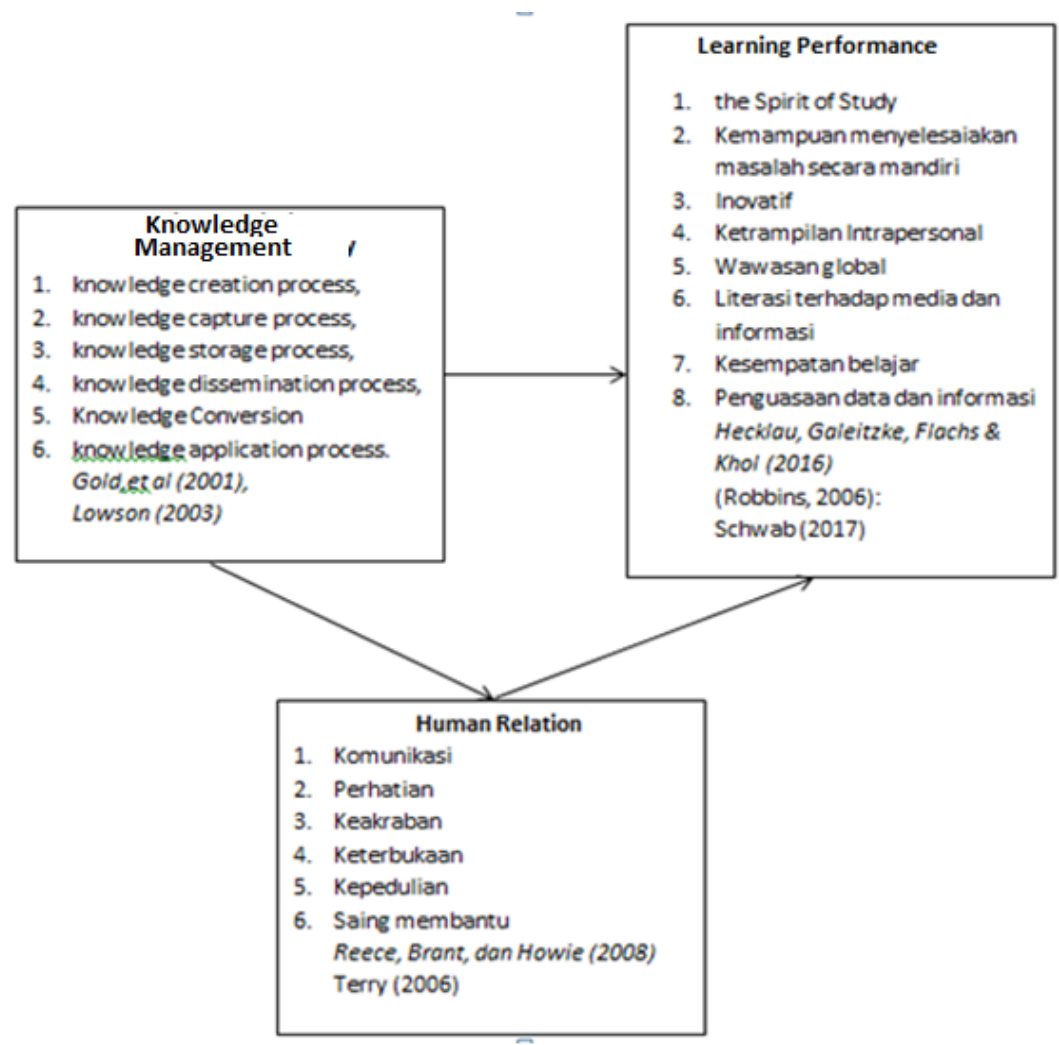

Sumber: Kajian Literatur Diolah (2020)

Hasil

Berdasarkan pengujian validitas indikator dianggap valid jika nilainya di atas 0,5 . Menurut Ghozali (2008) suatu indikator dianggap valid jika memiliki nilai korelasi di atas 0,70 . Namun untuk loading 0,50 sampai 0,60 masih dapat diterima dengan melihat output korelasi antara indikator dengan konstruknya. Hasil pengujian validitas menggunakan smartPLS dapat dilihat pada gambar 2. 


\section{Gambar 2. Hasil PLS Algoritma}

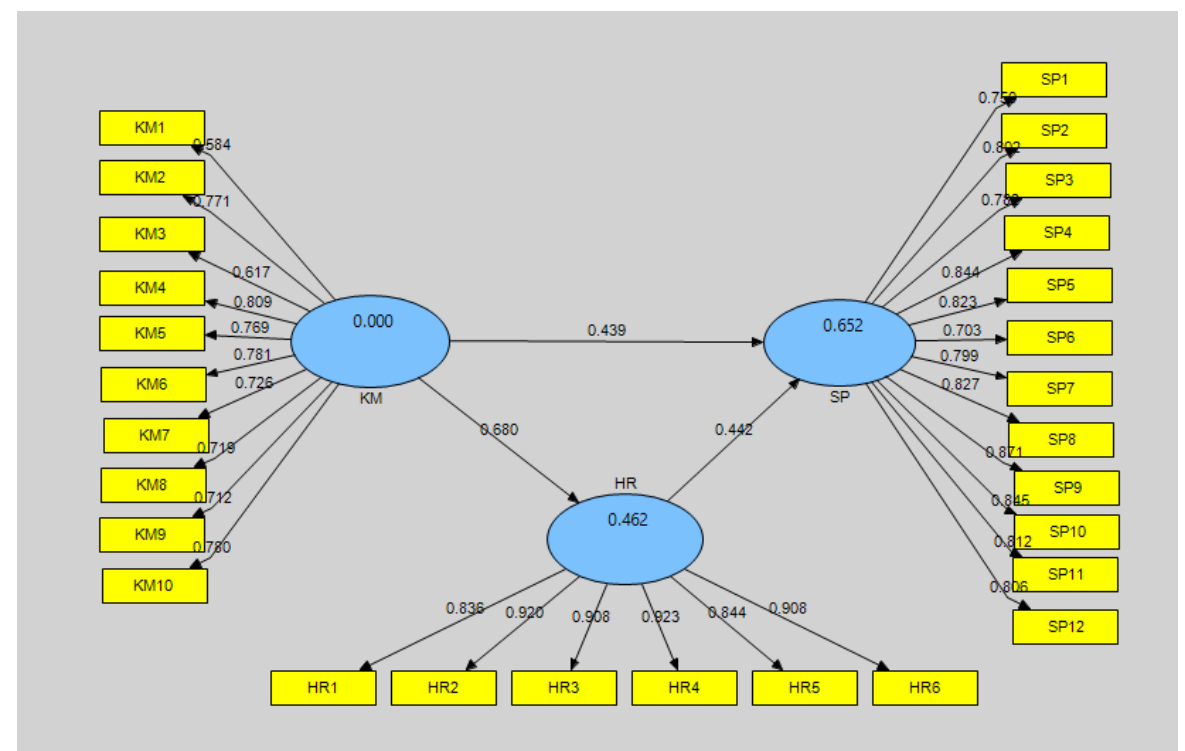

Sumber: Data Diolah (2020)

Berdasarkan pengujian validitas semua indikator dianggap valid karena hasil loading factor pada outer loading PLS Algoritma begitu pula hasil PLS Bootstraping menunjukkan nilai di atas 0,5 seperti terlihat ,Ghozali (2008). Nilai loading factor yang cukup besar menunjukkan bahwa setiap dimensi dan indikator mempengaruhi variabel latennya dengan cukup kuat. Sehingga bisa dikatakan manajemen pengetahuan di Perguruan Tinggi dapat ditingkatkan efektivitasnya apabila dimensi-dimensi yang ada pada tabel 1 dikelola dengan baik. Hal yang sama juga berlaku pada hubungan sesama manusia dan kinerja institusi pendidikan yang juga akan semakin meningkat sejalan dengan pengelolaan yang lebih baik pada dimensi-dimensi yang ada pada tabel 2 dan 3 . Dari pengujian didapat korelasi indikator semua konstruk memiliki nilai lebih tinggi dibandingkan dengan korelasi indikator tersebut terhadap konstruk lain, sehingga dikatakan konstruk memiliki discriminant validitas yang tinggi. Uji reliabilitas dilakukan dengan melihat nilai composite reliability dari blok indikator yang mengukur konstruk. Menurut Ghozali (2008) hasil composite reliability akan menunjukkan nilai yang memuaskan jika di atas 0,7. Hasil composite reliability menunjukkan nilai yang memuaskan yakni di atas 0,7 . Hasil uji model struktural menunjukkan R Square pada konstruk endogen di atas moderat, HR 0.46 dan SP 0.65. Nilai R-square ini berfungsi menjelaskan kemampuan independent variable menjelaskan dependent variable. Menurut Ghozali (2011) nilai R square sebesar 0.67 (kuat), 0.33 (moderat) dan 0.19 (lemah).

Tabel 1. Path Coefficients (Mean, STDEV, T-Values)

\begin{tabular}{ccc} 
& Original Sample $(\mathrm{O})$ & T Statistics (|O/STERR|) \\
\hline $\mathrm{HR}->\mathrm{SP}$ & 0.442240 & 4.992122 \\
$\mathrm{KM} \rightarrow \mathrm{HR}$ & 0.679624 & 13.235240 \\
$\mathrm{KM}$-> SP & 0.439182 & 6.769240 \\
\hline
\end{tabular}

Sumber: Data Diolah (2020)

Berdasarkan tabel 1 dapat dijelaskan bahwa KM memiliki pengaruh positif terhadap SP sebesar 0.44. Sehingga bisa dikatakan apabila pengelolaan Strategi manajemen pengetahuan ditingkatkan kualitasnya maka kinerja institusi pendidikan akan meningkat pula. Hipotesis H1 diterima karena nilai T statistik sebesar 3.96 yang berarti lebih besar dari 2.01 nilai $t$ table sehingga dapat dikatakan KM mampu menjelaskan pengaruh yang signifikan terhadap SP.

KM memiliki pengaruh positif terhadap HR sebesar 0.68 . Hal ini menunjukkan pengaruh yang cukup kuat dari pengelolaan Strategi manajemen pengetahuan terhadap hubungan sesama manusia di Perguruan Tinggi. Hipotesis $\mathrm{H} 2$ diterima karena nilai T statistik sebesar 13.2 yang berarti lebih besar dari 2.01 nilai t table sehingga dapat dikatakan KM mampu menjelaskan pengaruh yang signifikan terhadap HR. 
HR memiliki pengaruh positif terhadap SP sebesar 0.44. Sehingga apabila hubungan sesama manusia di Perguruan Tinggi diperbaiki maka kinerja institusi pendidikan juga akan meningkat secara moderat. Hipotesis $\mathrm{H} 3$ diterima karena nilai T statistik sebesar 4.99 yang berarti lebih besar dari 2.01 nilai t table sehingga dapat dikatakan HR mampu menjelaskan pengaruh yang signifikan terhadap SP.

\section{Kesimpulan}

Dalam rangka meningkatkan kinerja institusi pendidikan di dalam menghadapi revolusi industri 4.0, Perguruan Tinggi harus meningkatkan semangat belajar (the spirit of study), kemampuan menyelesaikan masalah, inovatif, ketrampilan intrapersonal, wawasan global, kemampuan literasi terhadap media dan informasi, kesempatan belajar, penguasaan data dan informasi karena semua dimensi ini terbukti mempengaruhi cukup kuat. Hubungan sesama manusia di Perguruan Tinggi akan meningkat apabila ada ada peningkatan pada dimensi Komunikasi, Perhatian, Keakraban, Keterbukaan,Kepedulian dan Saing membantu antar sivitas akademika. Strategi manajemen pengetahuan akan lebih efektif apabila proses knowledge creation, knowledge capture, knowledge storage, knowledge dissemination, knowledge conversion dan knowledge application ditingkatkan.

Penerapan Strategi manajemen pengetahuan pada perguruan tinggai terbukti dapat meningkatkan kinerja institusi pendidikan secara moderat. Ini sesuai dengan penelitian Zwain, Lim, Ko \& Othman (2012) yang menyatakan adanya hubungan yang kuat antara strategi manajemen pengetahuan dengan kinerja institusi pendidikan. Strategi manajemen pengetahuan juga terbukti berpengaruh kuat dalam meningkatkan hubungan sesama manusia kepada para student. Ini sesuai dengan pernyataan Kumalasari, Renna, et al bahwa information sharing dan knowledge sharing berpengaruh positif terhadap relationship. Hubungan sesama manusia dapat menjadi variabel mediator hubungan strategi manajemen pengetahuan dan kinerja institusi pendidikan dan mempunyai pengaruh yang sama besar dengan pengaruh langsung strategi manajemen pengetahuan terhadap kinerja institusi pendidikan. Ini sesuai dengan pernyataan Ngoc \& Huy (2016) yang menyatakan hubungan sesama manusia dapat menjadi perantara untuk meningkatkan kinerja di universitas.

\section{Daftar Pustaka}

Al-Rahmi, W. Mugahed, et. Al. (2018). A model of factors affecting kinerja institusi pendidikan through the use of social media in Malaysian higher education. Computers \& Education, 121. https://doi.org/10.1016/j.compedu.2018.02.010.

Center for Research and Development Academic Achievement (CRIRES) (2005). Data taken from International Observatory on Academic Achievement. Retrieved from http://www.criresoirs.ulaval.ca/sgc/lang/en_CA/pid/5493

Davis, Keith. (2009). Perilaku dalam Organisasi. Jakarta: PT. Pustaka Binawan

Ghozali, Imam. (2006). Structural Equation Modelling Metode Alternatif dengan Partial Least Square. Semarang, Universitas Diponegoro.

Hargis, C.H. (2003). Grades and Grading Practices. Obstacles to Improving Education 114 and to Helping At-

Risk Students (2nd ed.) Springfield, IL: Thomas.

Hidayat, A. (2013). Tri Dharma perguruan Tinggi dan Produktivitas Dosen. Jurnal Teknologi Informasi (Telkom), $1(5)$,

Jutidharabongse, Jaturon \& Aujirapongpan, Somnuk \& Ritkaew, Supit. (2020). Strategi manajemen pengetahuan and strategic intuition of Thai entrepreneurs. Entrepreneurship and Sustainability Issues. 7. 2955-2966. 10.9770/jesi.2020.7.4(25).

Iqbal, A., Latif, F., Marimon, F., Sahibzada, U.F. and Hussain, S. (2019). From Strategi manajemen pengetahuan to organizational performance: Modelling the mediating role of innovation and intellectual capital in higher education. Journal of Enterprise Information Management, Vol. 32 No. 1, pp. 36-59. https://doi.org/10.1108/JEIM-04-2018-0083

Lase, Delipiter. (2019). Education and Industrial Revolution 4.0. 10. 48-62. 10.24114/jh.v10i1.

Karnawati, Dwikorita (2017). revolusi industri 4.0. http://marketeers.com/mengenal-marketing4-0-dalam-konteksekonomi-digital/ 
Kumalasari, Renna, et al. (2013). Analisa Pengaruh Information Sharing, Knowledge Sharing, Relationship Terhadap Performance Di Hotel X. Jurnal Hospitality dan Manajemen Jasa, vol. 1, no. 2, 2013, pp. 230239.

Liffler, M., \& Tschiesner, A. (2013). The Internet of Things and the Future of Manufacturing. McKinsey \& Company

Linn, R.L. \& Gronlund, N.E. (1995). Measurement and Evaluation in Teaching, (7th ed.). Englewood Cliffs, NJ: Prentice-Hall.

Ngoc \& Huy (2016). Organizational Learning in Higher Education Institutions: A Case Study of A Public University in Vietnam. Journal of Economics and Development, Vol.18, No.2, August 2016,

Schawab (2016). Industry 4.0: the challenges of the transforming manufacturing. Germany: BPIFrance.

Siagian, Sondang P. 2012. Kiat Meningkatkan Produktivitas Kerja. Jakarta: PT Rineka Cipta

Smith, Mark Easterby and Prieto, Isabel M. (2008). Dynamic Capabilities and Knowledge Management: an Integrative Role for Learning?. British Journal of Management, Vol. 19, 235-249 (2008) DOI: 10.1111/j.1467-8551.2007.00543.x

Yuniarsih \& Amartiwi. (2019). Implementasi Manajemen Pengetahuan pada Perguruan Tinggi Swasta di Kabupaten Garut. Jurnal Wacana Kinerja: Kajian Praktis-Akademis Kinerja dan Administrasi Pelayanan Publik. 22. 10.31845/jwk.v22i2.166.

Undang-undang Nomor 12 Tahun 2012 tentang Pendidikan Tinggi, Pub. L. No. 12 (2012). Indonesia.

Undang-undang Nomor 14 Tahun 2005 tentang Guru dan Dosen, Pub. L. No. 14 (2005). Indonesia.

Walsh, J.N.\& Lannon J. (2020) Strategi manajemen pengetahuan development in international non-governmental organisations. Knowledge Management Research \& Practice, DOl: 10.1080/14778238.2020.1785348

Zwain, Ammar \& Lim, Kong Teong \& Othman, Siti. (2012). Strategi manajemen pengetahuan and Academic Performance: An Empirical Study of Iraqi HEls. 